\title{
Structural Failure Trends of the Assembly Welding Fixture for the Front Sidewall on the basis of Finite Element Analysis
}

\author{
Duo Sun ${ }^{1, a}$, Tianmin Guan ${ }^{2}$ and Lei Lei ${ }^{1}$ \\ 1, 2, 3 School of Mechanical Engineering, Dalian Jiaotong University, Dalian 116028, Liaoning, China
}

\begin{abstract}
The operating conditions of the assembly welding fixture for the front sidewall have been analyzed in this paper, and all the typical conditions have been applied with the nonlinear finite element analysis of the contact, aiming to ensure the safe utilization of the assembly welding fixture for the front sidewall of tooling equipment for the production of rail vehicles. The potentially risky component locations are predicted and the weak spots are discovered on the basis of the analysis results of the static strength. The anticipation of the component failure trends shows a guiding role in the failure prediction in actual production and facilitates accident prevention.
\end{abstract}

\section{Introduction}

The assembly welding fixture for the front sidewall of buses as the processing and tooling equipment in a machinery factory, Ltd., has been applied for the assembly welding for the front sidewall of buses, and generally installed on the positioner of 10T. The finite element analysis has been applied on the assembly welding fixture for the front sidewall, aiming to ensure the safe, scientific and reasonable operation of the equipment. The component failure trends are predicted and the weak spots are discovered on the basis of the static strength simulation and stiffness calculation under various operating loads, providing guidelines for maintenance and facilitating accident prevention.

\section{Nonlinear finite element analysis of the contact}

As to the contact problem of highly nonlinear characteristics, the contact zone is unknown before solving the problem, and it is also indefinite that the surfaces are in contact or separate. Such surfaces may be suddenly varied depending on the loads, materials, boundary conditions and other factors. Besides, the friction needs to be calculated in most of the contact problems, and a few types of calculation methods and models are applicable to compute the friction. However, all of them are involved with nonlinear properties, making the solving of the problem difficult to converge.

The finite element software of ANSYS as a multipurpose finite element calculation program, can be utilized to solve structural, fluid, electric, electromagnetic and collision problems. The ANSYS supports three contact ways: point-point, point-surface and surface- surface, and the contact elements for each contact way are suitable for certain types of problems. To create a model of the contact problem, it's significant to firstly figure out which parts of the model may be contacted to each other. If one of the interactions is a point, the corresponding element of the model shall be a node. If one of the interactions is a surface, the corresponding element of the model shall be a cell, such as the beam element, shell element or solid element. The finite element model can be applied to identify potential contact pairs by means of the specified contact element.

\section{The finite element model for the assembly welding fixture of the front sidewall}

The 3D drawing software of $\mathrm{PRO} / \mathrm{E}$ is applied to model the three-dimensional assembly welding fixture for the front sidewall, and the HyperMesh v10.0 is employed to carry out finite element modeling on the equipment. The large-scale, general-purpose finite element analysis software of ANSYS is utilized to conduct the static strength analysis on the assembly welding fixture for the front sidewall. Such a fixture has been represented in terms of three-dimensional physical model, as shown in Fig. 1, in accordance with its drawing data and the relationship between various components on the drawings.

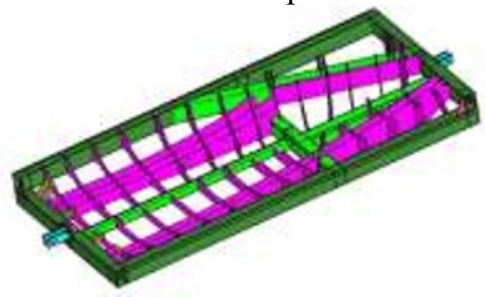

a. General assembly drawing

\footnotetext{
a Duo Sun: sddjtu@163.com
} 


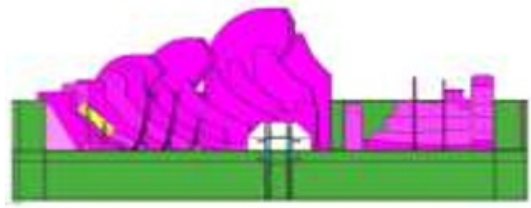

b. Parts drawing

Figure 1. Three-dimensional model for the assembly welding fixture for the front sidewall

Then the three-dimensional model is imported into HyperMesh for finite element meshing and developing a finite element model. Any structure that contributes to the overall stiffness and local strength of the assembly welding fixture for the front sidewall has been taken into account. The finite element model for the assembly welding fixture of the front sidewall as shown in Fig. 2, is mainly composed of hexahedral solid cells for the accuracy of computing.

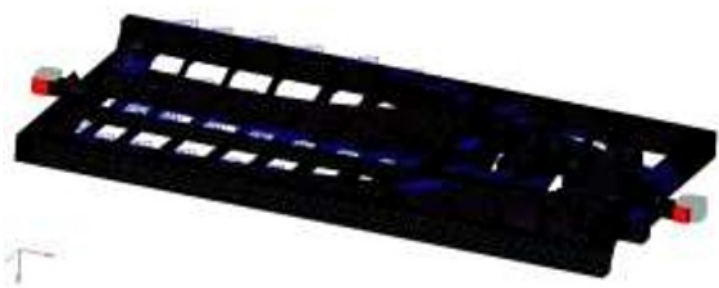

Figure 2. Overall view of the finite element model for the assembly welding fixture for the front sidewall

The contact pairs shall be defined after the finite element modeling for all components. Two methods are available to be selected for the surface-surface contact pairs: one is to select the solid-solid, and the other is to produce two shells on the two contact surfaces, applied to define the contact relationship between the surfaces of the two shell elements. Taking into account the large size of the equipment parts, the solid-solid contact increases the number of operations, hence it is reasonable to define the contact relationship between the surface shell elements and perform operations so as to facilitate the calculation. The defined contact surface is displayed in Fig. 3.

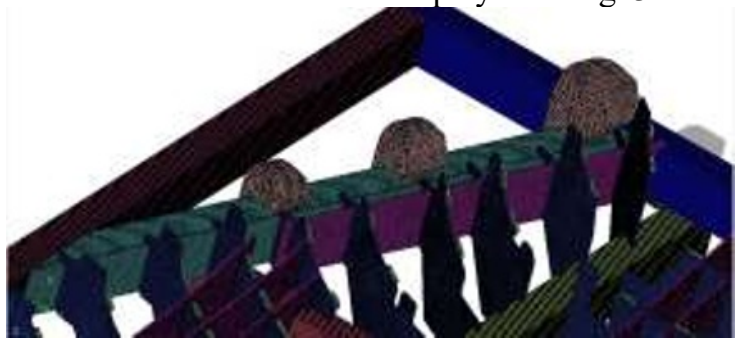

Figure 3. Schematic of the defined contact surface

\section{Load and boundary conditions}

The calculation results for each operating condition are accessible by virtue of the post-processing of ANSYS, and the deformation nephogram and Von. Mises stress nephogram can be obtained respectively under each operating condition. The positions for the second largest stress can be easily discovered after removing the maximum stress point, and the stress value can be displayed. Five stress points are selected for each operating condition in order to find as many of potentially risky locations as possible. The calculation results of static strength for the assembly welding fixture for the front sidewall are summarized in Table 2.

Table 1. The partial load conditions for the assembly welding fixture for the front sidewall

\begin{tabular}{|c|c|c|c|c|}
\hline No. & 1 & 2 & 3 & 4 \\
\hline $\begin{array}{c}\text { Load } \\
\text { conditions }\end{array}$ & $\begin{array}{c}\text { The rated } \\
\text { load } \\
\text { condition } \\
\text { at } 0^{\circ}\end{array}$ & $\begin{array}{c}\text { The rated } \\
\text { load } \\
\text { condition } \\
\text { at } 30^{\circ}\end{array}$ & $\begin{array}{c}\text { The rated } \\
\text { load } \\
\text { condition } \\
\text { at } 90^{\circ}\end{array}$ & $\begin{array}{c}\text { The rated } \\
\text { load } \\
\text { condition } \\
\text { at } 180^{\circ}\end{array}$ \\
\hline & $\mathrm{FZ}$ & $\mathrm{FZ}$ & $\mathrm{FZ}$ & $\mathrm{FZ}$ \\
\hline $\begin{array}{l}\text { Labels and } \\
\text { description }\end{array}$ & $\begin{array}{c}\text { Each } \\
\text { assembly } \\
\text { welding } \\
\text { fixture for } \\
\text { the front } \\
\text { sidewall }\end{array}$ & $\begin{array}{c}\text { Each } \\
\text { assembly } \\
\text { welding } \\
\text { fixture for } \\
\text { the front } \\
\text { sidewall }\end{array}$ & $\begin{array}{c}\text { Each } \\
\text { assembly } \\
\text { welding } \\
\text { fixture for } \\
\text { the front } \\
\text { sidewall } \\
\end{array}$ & $\begin{array}{c}\text { Each } \\
\text { assembly } \\
\text { welding } \\
\text { fixture for } \\
\text { the front } \\
\text { sidewall }\end{array}$ \\
\hline $\begin{array}{c}\text { Load } \\
\text { values }\end{array}$ & $7840 \mathrm{kN}$ & $7840 \mathrm{kN}$ & $7840 \mathrm{kN}$ & $7840 \mathrm{kN}$ \\
\hline $\begin{array}{c}\text { Positions } \\
\text { of the loads } \\
\text { applied }\end{array}$ & $\begin{array}{c}\text { Chassis } \\
\text { center }\end{array}$ & $\begin{array}{c}\text { Chassis } \\
\text { center }\end{array}$ & $\begin{array}{c}\text { Chassis } \\
\text { center }\end{array}$ & $\begin{array}{c}\text { Chassis } \\
\text { center }\end{array}$ \\
\hline
\end{tabular}

The Fig. 4 shows the positions of the displacement constraints and load conditions applied on the assembly welding fixture for the front sidewall under the rated load conditions at $0^{\circ}, 30^{\circ}, 90^{\circ}$ and $180^{\circ}$.

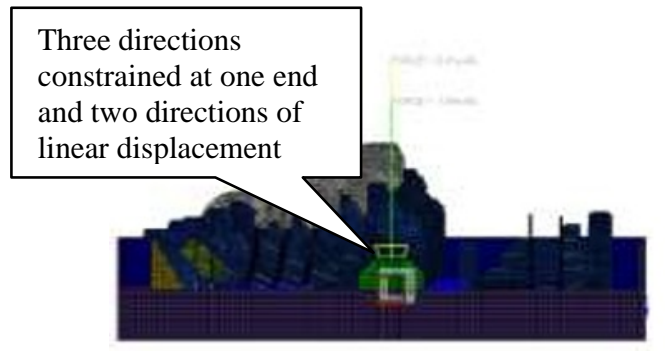

a. Rated load condition at $0^{\circ}$

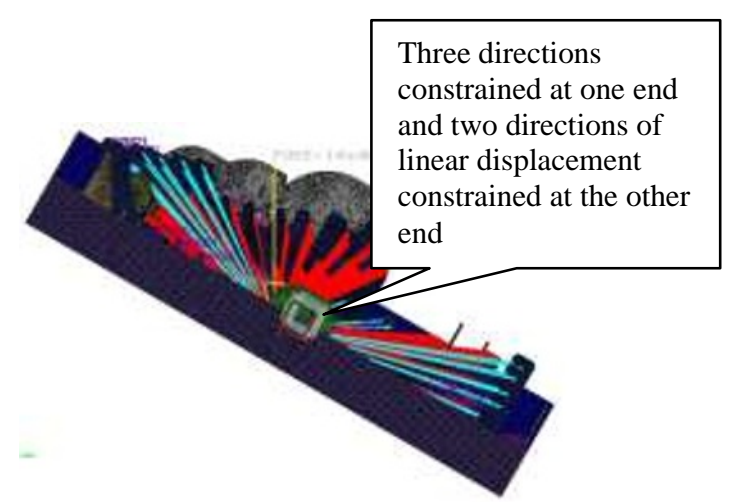

b. Rated load condition at $30^{\circ}$ 


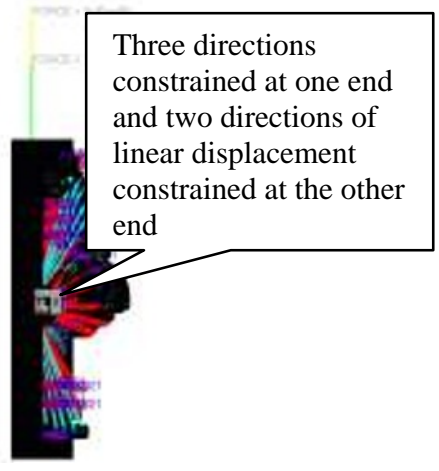

c. Rated load condition at $90^{\circ}$

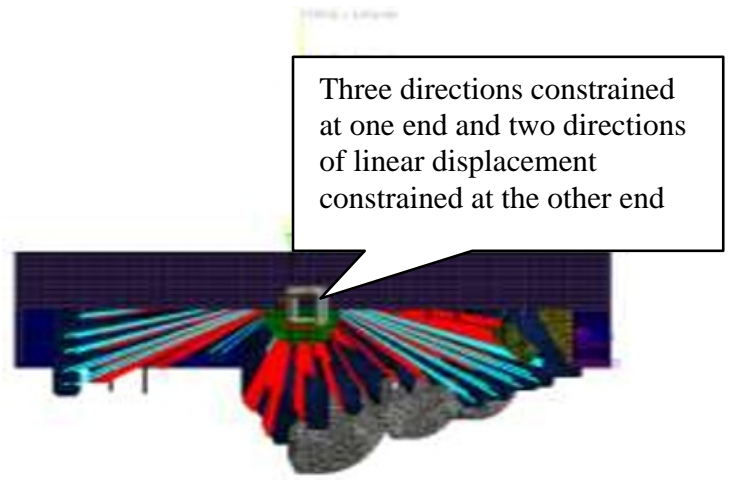

d. Rated load condition at $180^{\circ}$

Figure 4. Schematic of the loading positions on the assembly welding fixture for the front sidewall

\section{Calculation results of static strength}

The calculation results for each operating condition are accessible by virtue of the post-processing of ANSYS, and the deformation nephogram and Von. Mises stress nephogram can be obtained respectively under each operating condition. The positions for the second largest stress can be easily discovered after removing the maximum stress point, and the stress value can be displayed. Five stress points are selected for each operating condition in order to find as many of potentially risky locations as possible. The calculation results of static strength for the assembly welding fixture for the front sidewall are summarized in Table 2.

From the results in Table 2, it can be seen that the operating condition 3 is the riskiest one since the deformation and stresses at each location are the maximum values under each operating condition. Thus the operating condition 3 shall be avoided as much as possible during the usage of the equipment.

The maximum stress of the equipment takes place in the elliptical hole at the extended end, hence the surface of the elliptical hole shall be monitored.

The main stress point appears at the welding positions between the extended end and the crossbeam in the operating state. Based on the comprehensive consideration of strain and stress, the welding positions between the extended end and the crossbeam, rib plate as vulnerable parts tend to cause equipment failure, thus such positions ought to be conducted with $100 \%$ UT inspection. The followed are the welding positions between various supporting plates and crossbeam, longitudinal beam.

From the analyzed strain and stress nephogram it can be seen that significant stresses and deformation also take place at the welding positions between small longitudinal beam and crossbeam, supporting plate, consequently special attention shall be paid to their overhauling and maintenance.

Table 2. Calculation summary of the nonlinear static strength for the assembly welding fixture for the front sidewall

\begin{tabular}{|c|c|c|c|c|c|}
\hline & $\begin{array}{l}\text { llation } \\
\text { litions }\end{array}$ & $\begin{array}{c}\text { Operati } \\
\text { ng } \\
\text { conditio } \\
\text { n 1 }\end{array}$ & $\begin{array}{c}\text { Operati } \\
\text { ng } \\
\text { conditio } \\
\text { n } 2\end{array}$ & $\begin{array}{c}\text { Operati } \\
\text { ng } \\
\text { conditio } \\
\text { n } 3\end{array}$ & $\begin{array}{c}\text { Operati } \\
\text { ng } \\
\text { conditio } \\
\text { n } 4\end{array}$ \\
\hline & $\begin{array}{l}\text { imum } \\
\text { mation } \\
\mathrm{am} \text { ) }\end{array}$ & 0.076 & 0.091 & 0.170 & 0.095 \\
\hline & $\begin{array}{l}\text { Maximu } \\
\mathrm{m} \text { stress }\end{array}$ & 14.3 & 17.2 & 17.6 & 12.6 \\
\hline Von. & $\begin{array}{l}\text { Second } \\
\text { largest } \\
\text { stress } 2\end{array}$ & 10.7 & 12.8 & 12.8 & 9.7 \\
\hline $\begin{array}{c}\text { Mise } \\
\text { S } \\
\text { stres }\end{array}$ & $\begin{array}{l}\text { Second } \\
\text { largest } \\
\text { stress } 3\end{array}$ & 8.6 & 10.3 & 10.4 & 9.6 \\
\hline $\begin{array}{l}\mathrm{s} \\
\text { (MP } \\
\text { a) }\end{array}$ & $\begin{array}{l}\text { Second } \\
\text { largest } \\
\text { stress } 4\end{array}$ & 8.2 & 9.8 & 10.2 & 9.1 \\
\hline & $\begin{array}{l}\text { Second } \\
\text { largest } \\
\text { stress } 5\end{array}$ & 5.9 & 7.1 & 10.2 & 8.2 \\
\hline
\end{tabular}

The key monitoring positions are summarized for the assembly welding fixture for the front sidewall in Table 3.

Table 3 Summary of the key monitoring positions for the assembly welding fixture of the front

\begin{tabular}{|c|c|}
\hline No & Key monitoring positions \\
\hline 1 & Elliptical hole at the extended end \\
\hline 2 & $\begin{array}{c}\text { Location between the bottom plate at the extended } \\
\text { end and the rib plate of crossbeam }\end{array}$ \\
\hline 3 & $\begin{array}{c}\text { Welding positions between the longitudinal } \\
\text { supporting plate and crossbeam }\end{array}$ \\
\hline 4 & $\begin{array}{c}\text { Welding positions between small longitudinal } \\
\text { beam and crossbeam }\end{array}$ \\
\hline
\end{tabular}

\section{Conclusion}

Taking into account ensuring the safe, scientific and reasonable operation of the assembly welding fixture for the front sidewall, the operating conditions have been selected for the equipment in this paper, and the nonlinear finite element analysis of the contact has been applied for all the typical conditions. The potentially risky component locations take place in the elliptical hole at the extended end, the same positions as the actual fault, on the basis of the analysis results of the static strength. The weak spots are discovered and the component failure 
trends are predicted, providing guidelines for the failure prediction in actual production and facilitating accident prevention. In the meanwhile, the anticipation of the component failure trends may pave the way for creating a database of the equipment reliability analysis.

\section{References}

1. Qingwu Wang, Fang Zuo, Renxi Hu, et al. Advanced Applications of Mechanical Design by ANSYS 10.0 (second edition) [M]. China Machine Press, 2006, 1

2. Hongyun Li, Shexu Zhao, Yan Sun. ANSYS 10.0 Foundations and Applications in Engineering [M]. China Machine Press, 2008

3. Feifei Zhang, Hongwei Ma, Peng Chai. Optimization Design of FSW Fixtures based on Structural Static Analysis [J]. Tooling Equipment, 2010, 1 